\title{
THE CHANGING ROLE OF TOURISM POLICY IN SINGAPORE'S CULTURAL DEVELOPMENT: FROM EXPLICIT TO INSIDIOUS
}

\author{
CAN-SENG OOI \\ School of Social Sciences, University of Tasmania, Hobart, Australia
}

\begin{abstract}
In the last three decades, Singapore has transformed from a cultural desert to a global arts city, thanks significantly to tourism. The Singapore Tourism Board was proactively shaping the cultural dynamics and policy of Singapore until 2012. But since then its official role in the country's arts and cultural development almost disappeared. The disappearance of tourism interests in cultural development stems apparently from years of resistance, dialogues, and negotiation. This study argues that the tourism authorities are still maintaining influence in the cultural dynamics and development of Singapore by reframing its involvement. It insidiously asserts its influence by enticing members of the arts community with resources, opportunities, and economic support to participate in the tourism industry. This article provides a dialogical understanding of how tourism has shaped Singapore's cultural dynamics. Cultural dynamics and tourism development in Singapore must be understood within economic and social engineering perimeters defined by the government. The tourism authorities do not only work with other government authorities, they use similar techniques in managing and controlling cultural development in the city-state. The Bakhtinian Dialogic Imagination is the heuristic that organizes and structures the complex and dynamic tourism-culture relations in this study. Three dialogical concepts — carnivalesque, heteroglossia, and polyphony — are used. Besides documenting the ongoing evolution of tourism in the cultural development of Singapore, this study questions the effectiveness of the arm's length approach to managing cultural development. The Singapore case shows that there are subtle economic and political ways to go round that principle.
\end{abstract}

\section{Key words: Cultural policy; Carnivalesque; Dialogic imagination; Heteroglossia;} Polyphony; Touristification

\section{Introduction}

Tourism is sometimes used as an economic justification for promoting the arts and culture. But tourism's influence on cultural development often faces resistance from the local and arts communities. Using the case of Singapore, this study presents and evaluates the checkered relationships between the arts, culture and tourism in the city-state. Singapore has been transformed from a cultural desert to a 
cultural city over the decades, thanks significantly to tourism (H. C. Chan, 2015; Wee, 2003). In 1995, the Singapore Tourism and Promotion Board (now Singapore Tourism Board or STB) created a vision of Singapore as a Global City for the Arts (Singapore Tourist Promotion Board \& Ministry of Information and the Arts, 1995). Since then pop concerts by international acts (e.g., Lady Gaga, Jay Chou), fine art exhibitions by world renowned artists (e.g., Andy Warhol, Damien Hirst), popular musicals (e.g., Lion King and Mama Mia!), and arts festivals have become common. STB was also central in devising a cultural blueprint for the island that led to the founding of the National Museum, Asian Civilisations Museum, Singapore Art Museum, and the National Gallery (Ooi, 2005). But the role of tourism in the cultural dynamics and development of Singapore has become less explicit and obvious in recent years. The apparent disappearance of tourism's influence in cultural development policy stems from years of resistance, dialogues, and negotiation among members of the art community, the public, government boards, and tourism bodies. This article presents the dialogic processes involved, and demonstrates how tourism and cultural development goals are part of a wider economic and social engineering scheme in the governing of Singapore. Even though the development of the arts and culture is no longer officially driven by purposes of tourism, that industry's influence stays pertinent. In other words, the role of tourism policy in Singapore's cultural dynamics and development has changed from explicit to insidious.

Culture is a broad, vague, and ambiguous concept (Williams, 1976). Its multiple manifestations include a way of life in a community, abstract symbolic expressions such as in theater and paintings, and traditions and heritage that moor the identity of a society. These interrelated and different types of cultural manifestations are often packaged for tourist consumption and they share similar ambivalence towards touristification. Whether it is art performances, street food, or ancient artefacts, touristification or the empowering influence of tourism in shaping cultural development is often resisted in the local community (Ooi, 2013). On the other hand and in varying degrees, tourism and commercialism are part of cultural activities, like visiting the Statue of Liberty, having street food in
Hanoi, and enjoying Disneyland Paris. The divides between culture and economics are unclear, if not artificial. It is common that culture changes because of economic impetuses, with tourism being one of these impetuses. Similarly, the divide between high and low culture is fluid. Although not exclusively, this study will focus on the abstract and symbolic expressions of culture, more popularly known as art. There are diverse types of cultural tourism products and each type is to be appreciated in its own term. The cultural product examples in this article must thus be understood in context. The manner in which tourism policy shapes different cultural manifestations is expectedly uneven and layered.

Included in the different cultural forms, the balance between tourism and cultural development is hard to define and is often negotiated and defined politically (Ooi, 2013; Prentice \& Andersen, 2007). For a destination, tourism will inevitably or otherwise shape the cultural dynamics of the host society. The search for a balance between tourism and cultural development assumes an inherent contradiction. This contradiction is based on the prevalent assumption that the arts and cultural development should not be adulterated by economic and political pressures (Stolnitz, 1960; Zangwill, 1999). In the context of art, policy makers should maintain an arm's length approach and respect the artistic integrity of art makers, for instance. Like censorship and political pressures, touristification is considered a danger to maintaining the independence and integrity of art making. Artists who bend to such pressures often draw criticisms. For example, Singapore River and Chinatown are popular tourist attractions and tourists, and an established local painter and sculptor is famous for his Singapore River and Chinatown works. A few Singapore artists would refer to this particular artist when it comes to the touristification of art. For instance, TS, a contemporary art maker said: "His works are the same for so many years. It is always scenes of the Singapore River and Chinatown. He still works on sculptures of coolies and bullock carts. It looks like he is working for STB" (personal communication).

The art-making context and the commercial context of tourism clash. To TS, an artist must renew and challenge oneself and not be dictated by commercial reasons. On the other hand, many artists 
need to support themselves economically. It is difficult for them to reconcile the art and commercial contexts. Singapore painter HNY used to sell water-color paintings through a souvenir shop in a popular tourist attraction. She did not see that as an issue. While cognizant of the criticisms against touristification, she justified that half her sales proceeds go to charity, and she was then a fledging artist. She is grateful that the souvenir shop gave her a chance and took a small consignment from her. She has stopped selling souvenir art, and does not disrespect those who do.

Besides the fear of touristification in the arts, criticisms of touristification in other aspects of society are also plentiful (Budeanu, 2009; Teo, 2002). But studies have also shown that, over time, seemingly negative cultural effects of tourism can be neutralized and appropriated (Knudsen \& Waade, 2010; Picard, 1995). The evolution of tourism involvement in local cultural dynamics is not the same in all societies, and neither is it expected to be evenly spread. The case of Singapore will illustrate how touristification of cultural development continues in the city-state but its presence has become more subtle in recent years. The emergent processes are dialogical. The evolving dynamics highlight the challenges in bringing together contrasting and conflicting art and tourism agendas. The Bakhtinian dialogic imagination will be used as a heuristic to organize the complexity and bring about new insights into the touristification of cultural development in Singapore. As will be demonstrated later, the dialogic perspective layers the contexts and voices in the emerging negotiation between tourism and cultural development with the aim of organizing the dynamic processes, while not oversimplifying the complexity. The next section elaborates on this.

\section{The Dialogic of Arts and Tourism}

The dialogic imagination assumes tensions of order and disorder in all social situations. It originates from literary theorist Bakhtin $(1981,1986)$. Bakhtin worked on literary texts but his approach has been adopted into the social sciences (Gardiner, Bell, \& Gardiner, 1998; Kotler, Hamlin, Rein, \& Haider, 2002; Ooi, 2014a; Webb, 2005). The dialogic perspective seeks social multiplicity and dynamic processes. It offers a heuristic set of concepts and vocabulary to capture social phenomena in a dynamic and yet systematic manner. The framework organizes complexity rather than reduces the complexity. The emerging multiplicity of social contexts and voices in the Singaporean art and tourism worlds will be presented. The tensions inherent in Singapore's cultural dynamics, between order and disorder, will also be highlighted. For these purposes, three dialogic concepts - carnivalesque, heteroglossia, and polyphony - are utilized.

Carnivalesque points to the seeming disorder and yet orderly proceedings of the carnival (Bakhtin, 1984; Quantz \& O'Connor, 1988; Stallybrass \& White, 1986; Webb, 2005). All societies are heterogeneous and diverse but at the same time there are structure and order. Just as the carnival is dynamic and changing, resistance and negotiation in society are focused on the dialogic imagination. The multiple cultures and spheres of activities in society cannot be totally managed, suppressed, or controlled. As will be elaborated later, for instance, STB frames Singapore's diversity as a melting pot of the traditional and the modern, the East and the West, but to many tourists Singapore is understood as (sometimes too) clean, efficient, sanitized, and boring. Different people see order and disorder in the diversity and chaos of a society in their own ways. The carnivalesque accentuates senses of order and disorder. The interrelated concepts of heteroglossia and polyphony help provide a more layered reading of the carnivalesque.

Heteroglossia seeks out the multiple contexts embedded in social situations (Emerson \& Holquist, 1981, pp. 325-326; Holquist, 1981, p. 428; Vice, 1997, pp. 18-44), such as in cultural development and tourism. A social context entails a common understanding of what constitutes appropriate actions and how social practices are interpreted. Each context holds assumed agendas and purposes; for instance, as discussed before, cultural development should be from the ground up and not be driven primarily by tourism. Cultural development and tourism development have different goals and purposes, and some of these goals and purposes may complement but many others clash. Heteroglossia focuses on these meeting points and clashes, and highlights the different expectations and norms in different social contexts. The example of STB 
later shows how it was challenged when it was active in the cultural dynamics and policy development arena, and has now shifted its approach by not being in cultural policy development discussions but instead invite and entice cultural institutions and art makers to voluntarily participate in the tourism context. Subsequently, the touristification of the arts and culture debate is neutralized as members of the cultural community has a choice to be part of the tourism industry, and tourism is then framed merely as an incidental resource and opportunity for cultural development.

Polyphony is a concept related closely to heteroglossia. Polyphony draws attention to multiple voices (Emerson \& Holquist, 1981, pp. 331-336; McGee, 1986, pp. 112-113; Vice, 1997, pp. 112148). In a novel, for instance, polyphony not only points to voices of various characters but also to the overarching "silent" voice of the narrator. So in this article, my voice is omnipresent even though I rarely use the personal pronoun here. Voicesloud or hidden - do not just articulate the contexts in social situations, they also articulate the clashes and interplay of social contexts. For instance, a destination is filled with diverse artistic and cultural expressions but tourism promotion materials often weave a story to create a more coherent place narrative. In multicultural Malaysia, Cantonese operas, Indian dances, Malay martial art performances, modern street art, and many other cultural expressions are found in the country. The Malaysian tourism authorities have knitted a narrative that brings together the cultural diversity into a more comprehensible story, namely "Malaysia-Truly Asia," even though many tourists and most residents may have their own narratives (Lai \& Ooi, 2015; Musa, 2000). Polyphony draws attention to multiple voices and how these multiple voices challenge, complement, and are brought together. Some voices are louder than others. Again, as the case of Singapore will show, the tourism authorities' voice has been reduced to a whisper in the cultural development policy arena today but speaks loudly when it comes to attracting the local arts and cultural community to join the STB in the tourism arena.

The carnivalesque, heteroglossia, and polyphony are concepts fundamental to the dialogic imagination. They locate and organize complexity, ambiguity, ambivalence, order, and disorder in the social environment. Figure 1 presents the main stakeholders or parties in the cultural development of Singapore. The STB and the National Art Council (NAC) are government bodies that not only promote tourism and the arts, respectively, they are part of the country's wider social engineering machinery. As will be elaborated later, they propagate messages that fit into the country's multicultural logic. Many art makers and cultural institutions desire support and recognition from the NAC, and lament the lack of distance between politics and economics from the country's cultural development policy. Besides the arts and cultural events, many local community activities are being marketed and packaged for tourist consumption. The dialogic imagination is being exercised to understand the evolving relations between tourism and cultural development in Singapore in the subsequent sections. But before that and in the spirit of dialogism, the next section provides methodology notes and reflections on this study.

\section{Dialogic Imagination: \\ Methodology Notes and Brief Reflections}

This article is part of an ongoing investigation of tourism and art worlds in Singapore. Formal interviews, informal discussions, observations, and participant observation data were collected since 1996, together with documents and media reports. Figure 1 provides a representation of the dialogic imagination in this article. It points to the various stakeholders and players in tourism and cultural development in Singapore. As a Singaporean researcher who works overseas but return to his home country every year for a few weeks for research, I have spoken to and interacted with various members of the different groups involved. Many have become friends and acquaintances. And over the years I gave talks and seminars in research institutes and in cultural institutions there. I have provided my analyses to the tourism and arts communities. I occasionally publish letters in The Straits Times, the most read newspapers in the country. I am not a "neutral" party and do not pretend to be one. As embedded in the concepts of polyphony and cacophony, the dialogic imagination demands that researchers acknowledge their 


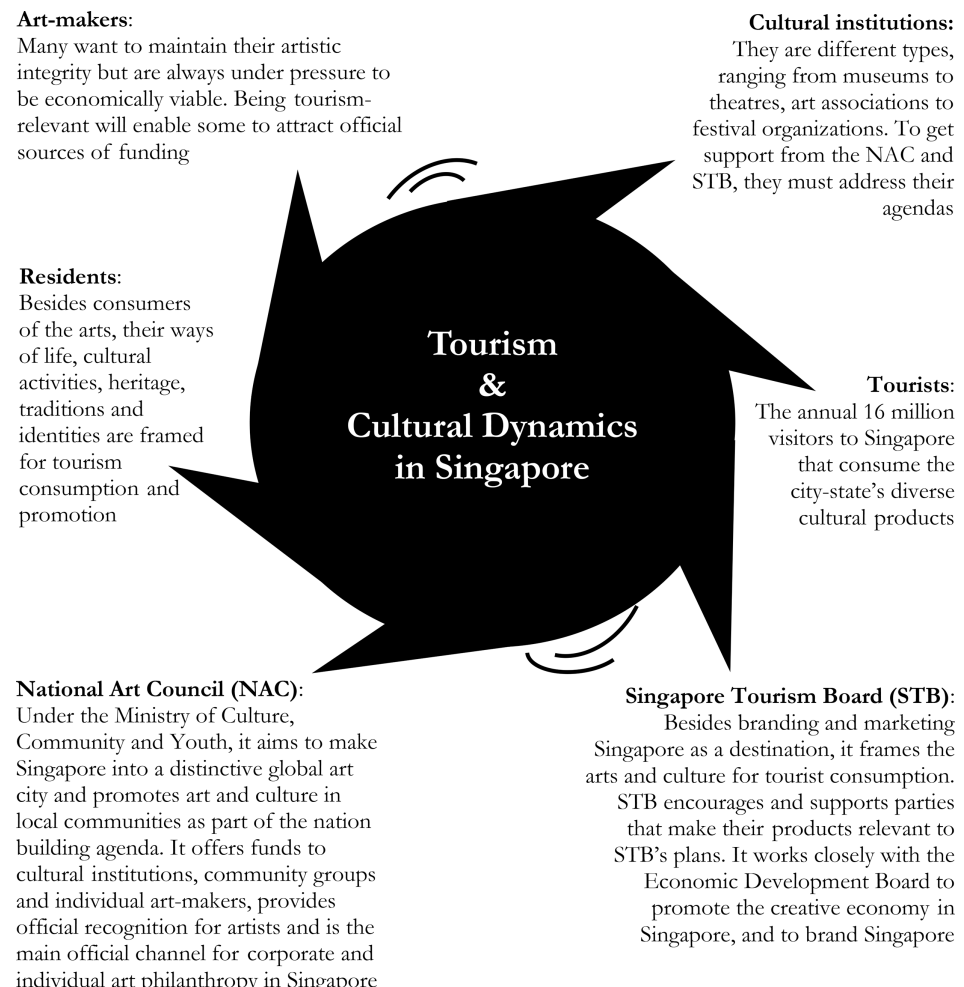

individual art philanthropy in Singapore

Figure 1. A dialogic spinning-wheel framework: Major stakeholders and their main interests in tourism and cultural development in Singapore.

positions. The researcher contributes to the knowledge generation process, and not just one who collects "unadulterated" views. It is important to present multiple and contrasting perspectives and interpretations to accentuate and illustrate the dialogic processes. This article is an attempt. The aim is to present the diversity and complexity of the situation in an organized and analytical manner. To aid in the narrative creation process, I have taken a chronological approach to show how tourism policy has remained important in shaping Singapore's cultural dynamics and development even though STB's explicit presence has seemingly disappeared.

Reflections on researcher-field relationships is part of the dialogic methodology. I have deep respect for the STB in developing Singapore into a popular destination but am also very sympathetic towards the plights of art makers and cultural institutions in Singapore. These positions can be inferred from my earlier writings. More elaborate methodological reflections are founded in my previous publications (Koning \& Ooi, 2013; Ooi, 2001, 2014a).

\section{Short History of Tourism and the Cultural Development Policies in Singapore}

In the magazine, The Peak, Singapore writer and visual artist Wyn-Lyn Tan pondered on whether Singapore has finally become an art hub (W.-L. Tan, 2015). As an established painter, she experienced the transformation of the citystate into a vibrant arts and cultural destination. Singapore's tourism strategy has evolved over the last five decades, with the arts and culture becoming more central in the last two decades. In Singapore various government agencies, including the STB, work together to further common economic and political agendas (C. B. Chan, 2002). For instance in 1995, the then Singapore Tourist Promotion Board and the then 
Ministry of Information and the Arts took the initiative to make Singapore into a "Global City for the Arts" (Singapore Tourist Promotion Board \& Ministry of Information and the Arts, 1995). In that blueprint, among other things, Singapore will develop its arts trading sector, attract global artists to perform there, and establish the Asian Civilisations Museum, the Singapore Art Museum and the National Museum of Singapore. The aim is to make Singapore into the art and cultural capital of Southeast Asia. This 1995 report was based on the 1989 Report of the Advisory Council on Culture and the Arts, through which a number of initiatives were taken, including the formation of the NAC, developing art schools, and creating more museums (Advisory Council on Culture and the Arts, 1989). After two decades of fast economic growth, the Singaporean government acknowledged in the late 1980s that the city-state should build a society beyond economic development, and they commissioned the 1989 report. In 1995, tourism was used as the economic basis for promoting the arts and culture, and thus shaping Singapore's cultural dynamics. In 2000, the 1995 initiatives were entrenched further into the "Renaissance City" blueprint (Ministry of Information and the Arts, 2000; K. Tan, 2007). As the term implies, Singapore should be an economically, scientifically, and not least culturally rich city. Renaissance City 2.0 was again prepared by the STB and released as part of a wider creative industries plan for Singapore (Economic Review CommitteeServices Subcommittee Workgroup on Creative Industries, 2002). Renaissance City III was published in 2008 (Ministry of Information Communication and the Arts [MICA], 2008). Until then the arts and culture, among other things, were seen as a resource for tourism and as an industry itself. But another arts and cultural development plan was released in 2012 (Arts and Culture Strategic Review, 2012). It was prepared by a cross-section of people in Singaporean society, including those in the arts community, academia, industry, STB, and other government boards. References to tourism in cultural development suddenly became minimal, and the industry is no longer a dominant voice in the official cultural policy development arena. The arts community has seemingly managed to exert a stronger presence in shaping Singapore's cultural dynamics. So instead the 2012 plan concentrates on community building (Said, 2017).

The Carnivalesque in Singapore's Cultural Dynamics: Order in Diversity and Heterogeneity

The images many people have of Singapore are diverse. After Brexit, UK politicians suggested that their country can be a regulation-light Singapore-on-Thames (Baschuk, Torsoli, \& Miller, 2017; Parker, Ford, \& Barker, 2017). In this case, Singapore is imagined as stable, efficient, cosmopolitan, outlook looking, and free-trade loving. On the other hand, an April 2017 episode of the popular American TV series, Criminal Minds: Beyond Borders, portrayed another side of Singapore (Lam, 2017a). Many local netizens ridiculed the show's portrayal of the island as a crime-ridden red-light slum. The official response came swiftly through STB, making snide references to the show through images of a culturally vibrant, modern, and orderly Singapore on their Facebook page (Lam, 2017b). There are many ways of organizing, interpreting, and understanding a heterogeneous Singapore. The cultural diversity of the island has a long history, dating back beyond its British colonial past.

The diversity of cultural activities, events, and institutions would seem rather messy without a narrative. The STB provides one. The STB narrative highlights and marginalizes aspects of Singapore by weaving together two dimensions: 1) imagining a vague divide between the East and the West, old and new Singapore; and 2) perpetuating Singapore's official multicultural message. These dimensions are not only aggressively propagated by the tourism authorities, they are also embedded in the state's various social engineering programs, shaping the city's cultural dynamics (Ooi, 2005, 2011). For instance, with regards to the East-West, oldnew divides, they have been used since the 1960s in branding Singapore. What constituted East and West, Old and New, however, changed over the decades. In the 1960s and 1970s, the then modernizing Singapore was framed as "Instant Asia," where one could find an array of esoteric Asian cultures, peoples, festivals, and cuisines conveniently exhibited in a progressing Third World country. In the 1980s, an economically strong Singapore was refashioned as "Surprising Singapore"; the 
island was presented through contrasting images of modernity and Asian mystique. The coexistence of East and West, old and new continued in the narrative into the 1990s. Singapore was then promoted as "New Asia-Singapore". There was a subtle shift in the focus from "Surprising Singapore" to "New Asia-Singapore". "Surprising Singapore" promised pockets of unexpected diverse and distinct ethnic cultures in a modern city, whereas "New Asia-Singapore" offered ethnic cultures fused into modern development. The "YourSingapore" branding, launched in 2010, again storied the destination in a similar East-West, old-new manner but as a buffet table of attractions that individual tourists can just pick-and-mix (Ooi, 2014b). In August 2017, the STB and the Economic and Development Board jointly launched a new brand for Singapore to attract both tourists and investors: "Passion Made Possible." The East-West, old-new frames remain but it focuses on the message that individuals (residents and tourists) can pursue their dreams with enthusiasm in Singapore (Kok, 2017; Leow, 2017).

The other cohering dimension in storying a carnivalesque Singapore is the official nation-building view of Singapore's diversity. Singapore's multiculturalism is marked by four ethnic groups: Chinese, Malay, Indian, and (a miscellaneous) Others (CMIO). These are the ethnic identities Singaporeans have to comply with in all their official dealings. So as a comprehensive term, all residents whose fore-parents come from India, even though from different parts of the subcontinent, spoke different Indian languages and carry different traditions are summarily grouped together into a single ethnic group "Indian." Scholars have debated on the CMIO model (Chang \& Teo, 2001; Leong, 1997). Regardless, STB has been central in perpetuating this message, for instance, in devising renewal plans for tourist areas such as Little India and Chinatown, and organizing cultural events (Lee, 2004).

In a heterogeneous Singapore, STB provides a storyline that offers some orderliness. These storylines help tourists who might be bewildered see order. This does not deny that many tourists and residents will interpret a culturally mixed Singapore in their own ways, based on their personal understanding and backgrounds. In the context of the cultural dynamics in Singapore, the STB vision of Singaporean cultural development has largely been implemented but has also been challenged over the years.

Heteroglossia in Singapore's Cultural Dynamics: Serving Tourism, Resisting Tourism

STB and tourism businesses are profit oriented and tourist focused. In contrast, most artists practice art with little concern for tourists. In many instances, deeper interest in commerce and popularity are detrimental to one's art practice (Ooi, 2010). Bringing the arts and tourism together leads to a number of clashes in maintaining artistic independence and furthering tourism interests.

After years of industry-centered cultural development policies, the arts is now seen to be part of the economic growth strategy of Singapore. The Economic Development Board (EDB) and the STB are working in tandem to foster a vibrant arts and cultural industry in the city-state. Mentioned earlier, they have jointly launched the latest "Passion Made Possible" branding of Singapore. To EDB, the arts is an emerging business and holds strong tourism and investment potentials (Ooi, 2007).

The businesses the authorities aim to get include auction houses, conservators, art logistics providers, art investment firms, and art printers. It has also set up a free port for art collectors to store their art works (S'pore' Freeport 'Not at Risk', 2014). Such businesses tie in well with attracting visitors. As an art capital, collectors, investors, and art lovers will come to Singapore. So, for instance, the STB has worked with the Singapore Art Museum to organize a special VIP itinerary for the Singapore Biennale. It engaged with the students of the local LaSalle College of the Arts in the 2015 ARTWALK Little India to curate and unveil art installations (Singapore Tourism Board, 2015). Many shopping malls in tourist areas in Singapore have art installations and/or art spaces, thanks to a scheme by the Urban Renewal Authority. In 2005, the Urban Renewal Authority introduced a scheme that allows developers to increase the gross floor area or built-up area on their pieces of land if the projects also support the arts (Urban Renewal Authority, 2009). Some local artists have benefited from the scheme; for instance, Singaporean artist Victor Tan 
has his stainless steel wire sculptures incorporated into the landscaped rooftop of Orchard Central, a premier shopping mall in the tourist district, and the iconic Orchard Ion shopping mail has a dedicated art space for ad hoc exhibitions.

But there is also resistance against the tourism agenda. For instance, the role of the Singapore Art Museum was questioned because massive resources were used to host blockbuster exhibitions that both tourists and locals can appreciate. The local art community was unhappy that money was spent on foreign works rather than on developing local cultural practices. A curator (A.M.) explained to me that tourists are more likely to visit exhibitions by internationally famous artists than by local ones. Tourists are necessary in "increasing the visitor numbers." Since the 2012 blueprint, the Singapore Art Museum changed its direction to supporting more local artists, while also trying to maintain visitor numbers (Martin, 2013).

Despite the policy proclamation of distancing of tourism concerns from the arts, artist, curator, and art entrepreneur, Alan Oei, who was the art director of the now-defunct Sculpture Square, remained skeptical. He was concerned that art policies in Singapore frame art as a tool, with the goal of drawing in more tourists or branding Singapore as a global city (Huang, 2013). Many cultural institutions and artists felt the pressure to become more economically sustainable, as they are compared to other creative businesses, such as in design and advertising. As part of the creative industries, questions were posed on why art makers are not creative enough to make money (Ooi, 2011). Regardless the authorities are cognizant of complaints in the art and cultural community. So since 2012 the official emphasize is community art. The resulting initiatives do not have a tourism focus, and they encourage community participation in everyday art. This response generated yet another set of complaints as members of the art community are worried that community art projects (e.g., drawing competitions in housing estates, weekly line-dancing classes, and setting up local community museums) are essentially social engineering activities and have little to do with aesthetics and quality of art. The criticisms against touristification of cultural development in Singapore have since lessened but criticisms against political and social engineering meddling continue (Lim, 2014; Rui, 2007). To many people, cultural integrity should be maintained without interference from tourism or political interests. More widely, the change in STB's approach is part of a change of control techniques by the Singaporean government, which is also reflected in censorship in the cultural spheres and the role of the NAC. This will be discussed next.

\section{Polyphony in Singapore's Cultural Dynamics: Silencing the Tourism Voice}

The 2012 Arts and Culture Strategic Review report stated:

\begin{abstract}
After decades of hard work to achieve our prosperity and security, we now have the cultural foundation and economic means to springboard to our artistic and cultural success. The time has come to focus on our identity, and strengthen the national unity that has brought us so far. Arts and culture will secure our identity amidst the multiplicity of global influences today, even as we remain open to the world. (p. 5)
\end{abstract}

The recommendations in the report have been accepted by the government. The main thrust is to create "a nation of cultured and gracious people, at home with our heritage, proud of our Singaporean identity" by 2025. The focus of cultural development in Singapore shifted away from tourism to nation building. As a result, policies are geared towards local participation in a diverse range of arts and cultural activities. Resulting from the new plan, visits to national museums are free for residents, commuters using the underground rail system enjoy art installations in the stations, arts and culture facilities in schools are enhanced with improved cocurricular activities, companies are encouraged to support the arts and culture as part of their corporate social responsibility, more classes and workshops are offered for hobbies and crafts, and arts and culture elements are integrated into wellness and hobbyist programs for senior citizens. As already mentioned, tourism is scantily cited in the plans but visitors are still considered key for some cultural institutions. 
More generally, the STB strategy is in line with that of the NAC. STB is no longer involved in shaping the cultural development policy of Singapore but it stills offer resources and support if members of the arts community want to enter the tourism arena. These participating cultural institutions and artists must then adhere to the demands of the STB. Similarly for the NAC, the policy is that members of arts community can do their own practice but if they want support and resources from the government board, the artists have to adhere to certain conditions. For instance, the then Chief Executive Officer of the NAC, Kathy Lai, responded to censorship complaints in the local art scene. While not directly censored, funding was withdrawn from recalcitrant arts groups and artists that are considered insulting and socially insensitive to certain quarters in Singapore. She maintained: "Those who advocate 'art for art's sake' and lament the arts are being 'instrumentalised' could reflect on whether it is such an ill if the arts are 'used' for the greater good of society" (K. Lai, 2015).

With reference to works and performances with critical political and social messages, she wrote in the same article in the local newspapers, The Straits Times:

Another important consideration is the recognition of the heterogeneity of our populace. We appreciate that some of our arts lovers are well-travelled, deeply engaged and want art that stimulate, provoke and disturb. But we also know there are others who want the arts to uplift them, to be simple expressions of joy and beauty. The one thing we won't - and must not - do is to be patronising or even insulting to audiences and potential audiences on their choices. (K. Lai, 2015)

The lack of a hands-off or arm's length approach to cultural development in Singapore has riled the art community and the public for decades (Chong, 2012; T. Lee, 2014; A. Tan, 2007). And for the NAC and Singaporean government, getting public support now means the art makers have moved into the nation-building arena, and away from the arts-for-arts-sake space. Ong Ken Sen, founding director of the Singapore International Festival of Arts and a Cultural Medallion (highest cultural recognition in Singapore) holder, bluntly criticized this and the need to focus on "friendly, accessible art," and to increase ticketing numbers (Ong \& Har, 2017):

What is happening right now is that a lot of government funding is coming with a lot of ties; ties like you can't talk about this or you can't talk about that. ... in order for the arts to remain in a place where we can still speak in relevant ways, we have to fund it ourselves.

Essentially the NAC does not see its role in the cultivation of a democratic and open cultural development agenda; instead the NAC sees its role as a nation-building and social engineering agency of the government. Artists and cultural institutions that receive support from the NAC have to comply with the NAC demands. STB uses the same logic. Even though STB is no longer a visible voice in the official cultural development plans, tourists remain vital for some cultural institutions and art practices. Like the tacit author in a text is ever present, STB continues to speak by offering opportunities to cultural institutions and artists. It still shapes Singapore's cultural dynamics. Activitiesperformances, activities, exhibitions - that interest tourists and are aligned to the cohering narrative of Singapore being a city where the East and West, old and new meet would get support. In a rather insidious manner, participation in tourism is then framed as voluntary. And the practice of getting direct support from STB has not changed over the decades; businesses and groups can apply for grants and resources to develop and package their products as long as they are in line with STB's goals (Singapore Tourism Board, 2019). In 2017 Singapore' standing as an international pop culture city was enhanced when STB developed a 3-year partnership (20172019) with Disney to host a number of Disneythemed events in Singapore, such as Star Wars Day on May 4, 2017 (Chua, 2017). Such schemes may tempt some artists and cultural institutions to gear their products and productions in that direction.

\section{Conclusion}

The relationship between tourism and cultural development in Singapore is a long negotiation. This article presents the cultural dynamics in that tenuous relationship, framed through the dialogic imagination. The situation is complex but some of 
the processes are unpacked through the concepts of carnivalesque, heteroglossia, and polyphony. There is order in the seemingly disorderly carnivalesque; there are meetings and clashes of contexts in heteroglossia; and there are different and changing voices. Over years of complaints, the tourism voice has become a whisper in cultural policy statements in Singapore. Even though the tourism focus has diminished in cultural policy aims, STB still offers opportunities and resources for artists and cultural institutions by inviting the arts community into the tourism arena.

This case shows how tourism and cultural development are driven by a common economic progress and social engineering program of the Singaporean government. Until recently, the tourism authorities have been explicit in not just managing and promoting the local tourism industries but also in shaping and ensuring that the arts and cultural dynamics in Singapore stay relevant to the tourism market while communicating nation-building messages. Undoubtedly the cultural scene has prospered and become more vibrant in the 1990s and 2000s, as resources are poured in to develop and enhance a cultural life that is interesting to both residents and tourists. The making of Singapore into a cultural capital is only possible with the economic resources and progress of the city-state. The enriched cultural scene of Singapore is also part of branding Singapore, with the aim of displaying the wealth and influence of the country in the region. The spheres of economic and cultural activities are intertwined as public resources are used to serve industry and community purposes. Such industry-community collaboration underpins Singapore's success. But over time, the constant clashes of interests and agendas have created challenges. It seems that tourism is no longer playing a big role in Singapore's cultural development. That is not true; it has just been reframed. It reflects a shift in the Singaporean government's tact in controlling the arts community. The explicit tourism voice may have disappeared in cultural development policies, but the tourism legacy presence still exists and cultural institutions and participants are encouraged to cross into the tourism arena to do their work. By doing so, they have to adhere to tourism needs. This is the same with getting funding from the NAC; artists have to adhere to government demands if they want support.
In other words, instead of infringing on the cultural by tourism, the tourism authorities encourage willing cultural parties to contribute to tourism. This shifts discussions on touristification to using tourism as a resource for cultural development. The latter is voluntary. Like what the NAC is doing, this new STB's approach is a more subtle and insidious manner of nudging the cultural community. Pressures on the economic sustainability of members of the arts and cultural community remain in Singapore; some will resist STB's overtures, others will not. Art makers who are enthusiastic and believe in their craft fit well into the "Passion Made Possible" branding of Singapore; the STB is at hand to support these artists if their practices fit the official tourism agenda.

Finally, in the context of this study, Bahktin's dialogic imagination has provided a set of lenses to organize and frame social complexity. Even though this perspective comes from literary studies, the emphasis on order and disorder, multiple contexts and diverse voices has accentuated resistance and compliance by various parties. The clashes of cultural and tourism interests and agendas continue, as the various parties devise new ways to further their own interests. For the tourism authorities in Singapore, they assert their influence by encouraging the cultural community to join them in the tourism arena, instead of having a dominant presence in the cultural arena. Time will tell how the local arts and cultural communities respond.

\section{References}

Advisory Council on Culture and the Arts. (1989). Report of the advisory council on culture and the arts. Singapore: Singapore National Printers.

Arts and Culture Strategic Review. (2012). The report of the arts and culture strategic review. Singapore. Retrieved from https://www.nac.gov.sg/dam/jcr:1b1765f3-ff95-48f0bbf9-f98288eb7082

Bakhtin, M. M. (1981). The dialogic imagination. Austin, TX: University of Texas Press.

Bakhtin, M. M. (1984). Problems of Dostoevsky's poetic. Minneapolis, MN: University of Minnesota Press.

Bakhtin, M. M. (1986). Speech genres and other late essays. Austin, TX: University of Texas Press.

Baschuk, B., Torsoli, A., \& Miller, H. (2017, April 12). EU won't back trade deal if Britain chooses "Singaporeon-Thames." Bloomberg. Retrieved from https://www. bloomberg.com/news/articles/2017-04-12/eu-won-t-backtrade-deal-if-u-k-chooses-singapore-on-thames 
Budeanu, A. (2009). Environmental supply chain management in tourism: The case of large tour operators. Journal of Cleaner Production, 17(16), 1385-1392.

Chan, C. B. (2002). Heart work. Singapore: Singapore Economic Development Board.

Chan, H. C. (2015, July 4). The arts power on. The Straits Times. Retrieved from https://www.straitstimes.com/ opinion/the-arts-power-on

Chang, T. C., \& Teo, P. (2001). From rhetoric to reality: Cultural heritage and tourism in Singapore. In L. Low \& D. M. Johnston (Eds.), Singapore Inc.: Public policy options in the third milennium (pp. 273-303). Singapore: Asia Pacific Press.

Chong, T. (2012). The theatre and the state in Singapore: Orthodoxy and resistance. London, UK: Routledge.

Chua, A. (2017, April 13). Star Wars, Disney-themed events to come to Singapore under Disney tie-up: STB. Today. Retrieved from https://www.todayonline.com/lifestyle/ stb-inks-3-year-collaboration-disney

Economic Review Committee-Services Subcommittee Workgroup on Creative Industries. (2002). Creative industries development strategy: Propelling Singapore's creative economy. Singapore: Author.

Emerson, C., \& Holquist, M. (Trans.). (1981). The dialogic imagination. Austin, TX: University of Texas Press.

Gardiner, M., Bell, M. M., \& Gardiner, M. (1998). Bakhtin and the human sciences: A brief introduction. In M. M. Bell \& M. Gardiner (Eds.), Bakhtin and the human sciences (pp. 1-12). London, UK: SAGE Publications.

Holquist, M. (1981). Glossary. In C. Emerson \& M. Holquist (Trans.), The dialogic imagination (pp. 423-434). Austin, TX: University of Texas Press.

Huang, L. (2013, January 7). The Life! Interview with Alan Oei: Putting the buzz into art. The Straits Times. Life! People section, p. 4.

Knudsen, B. T., \& Waade, A. M. (2010). Re-investing authenticity: Tourism, places and emotions. Bristol, UK: Channel View Publications.

Kok, X. H. (2017, August 25). Wooing tourists and firms with new tagline. The Straits Times. Retrieved from https:// www.straitstimes.com/singapore/wooing-tourists-andfirms-with-new-tagline

Koning, J., \& Ooi, C. (2013). Awkward encounters and ethnography. Qualitative Research in Organizations and Management: An International Journal, 8(1), 16-32.

Kotler, P., Hamlin, M. A., Rein, I., \& Haider, D. H. (2002). Marketing Asian places: Attracting investment, industry, and tourism to cities, states and nations. Singapore: John Wiley and Sons.

Lai, K. (2015, November 7). The tough balancing act of arts funding. The Straits Times. Retrieved from https://www. straitstimes.com/opinion/the-tough-balancing-act-ofarts-funding

Lai, S., \& Ooi, C.-S. (2015). Branded as a World Heritage city: The politics afterwards. Place Branding and Public Diplomacy, 11(4), 276-292.
Lam, L. (2017a, April 18). Criminal minds: Beyond borders depiction of Singapore slammed as inaccurate, misleading. Straits Times. Retrieved from https://www. straitstimes.com/lifestyle/entertainment/criminal-mindsbeyond-borders-depiction-of-singapore-slammed-asinaccurate

Lam, L. (2017b, April 21). Tourism board counters criminal minds: Beyond borders' depiction of Singapore. Straits Times. Retrieved from https://www.straitstimes.com/ singapore/tourism-board-counters-criminal-minds-beyondborders-depiction-of-singapore

Lee, P. (2004). Singapore, tourism and me. Singapore: Pamelia Lee Private Ltd.

Lee, T. (2014). "Inculcating" creativity: Culture as public pedagogy in Singapore. Discourse: Studies in the Cultural Politics of Education, 35(5), 718-732.

Leong, W. T. (1997). Commodifying ethnicity: State and ethnic tourism in Singapore. In M. Picard \& R. E. Wood (Eds.), Tourism, ethnicity, and the state in Asian and Pacific societies (pp. 71-98). Honolulu. HI: University of Hawaii Press.

Leow, A. (2017, August 25). Brand 'sends clear message on what S'pore has to offer.' The Straits Times. Retrieved from https://www.straitstimes.com/business/ economy/brand-sends-clear-message-on-what-sporehas-to-offer

Lim, L. (2014). Negotiation and adaptation: Singapore theater as civil society. In H.-K. Lee \& L. Lim (Eds.), Cultural policies in East Asia: Dynamics between the state, arts and creative industries (pp. 104-119). New York, NY: Palgrave Macmillan.

Martin, M. (2013, February 8). Visitors down, local artists up at SAM - does that sound good. Today. Retrieved from http://www.todayonline.com/blogs/forartssake/visitorsdown-local-artists-sam-does-sound-good

McGee, V. W. (Trans.). (1986). Speech genres and other late essays. Austin, TX: University of Texas Press.

Ministry of Information and the Arts. (2000). Renaissance City Report: Culture and the Arts in Renaissance Singapore. Singapore: Author.

Ministry of Information Communication and the Arts (MICA). (2008). Renaissance City Plan III. Singapore: Author.

Musa, G. (2000). Tourism in Malaysia. In C. M. Hall \& S. Page (Eds.), Tourism in south and southeast Asia: Issues and cases (pp. 144-156). Oxford, UK: ButterworthHeinemann.

Ong, K. Sen, \& Har, D. (2017). Outgoing SIFA director Ong Keng Sen on why the public should be paying for the arts. SG Magazine. Retrieved June 8, 2017, from http://sg.asia-city.com/events/news/outgoing-sifadirector-ong-keng-sen-why-public-should-be-payingarts

Ooi, C.-S. (2001). Mediated cultures: Production and consumption of Copenhagen and Singapore. Copenhagen, Denmark: Copenhagen Business School.

Ooi, C.-S. (2005). State-civil society relations and tourism: Singaporeanizing tourists, touristifying Singapore. 
Sojourn - Journal of Social Issues in Southeast Asia, 20(2), 249-272.

Ooi, C.-S. (2007). The creative industries and tourism in Singapore. In G. Richards \& J. Wilson (Eds.), Tourism, creativity and development (pp. 240-251). London, UK: Routledge.

Ooi, C.-S. (2010). Cacophony of voices and emotions: Dialogic of buying and selling art. Culture Unbound, 2, $347-364$.

Ooi, C.-S. (2011). Subjugated in the creative industries: The fine arts in Singapore. Culture Unbound, 3, 119-137. Retrieved from http://www.cultureunbound.ep.liu.se/v3/ a11/cu11v3a11.pdf

Ooi, C.-S. (2013). Tourism policy challenges: Balancing acts, co-operative stakeholders and maintaining authenticity. In M. Smith \& G. Richards (Eds.), Routledge handbook of cultural tourism (pp. 67-74). London, UK: Routledge.

Ooi, C.-S. (2014a). Accentuating complexity and ambiguity: Dialogism and its methodological implications. In J. W. Meged, B. S. Blichfeldt, L. A. Hansen, \& K. A. Hvass (Eds.), Tourism methodologies-New perspectives, practices and proceedings (pp. 155-174). Copenhagen, Denmark: Copenhagen Business School Press.

Ooi, C.-S. (2014b). The making of the copy-cat city: Accreditation tactics in place branding. In P. O. Berg \& E. Björner (Eds.), Branding Chinese mega-cities: Policies, practices and positioning (pp. 232-248). Cheltenham, UK: Edward Elgar.

Parker, G., Ford, J., \& Barker, A. (2017, January 20). Is Theresa May's Brexit plan B an elaborate bluff? Financial Times. Retrieved from https://www.ft.com/ content/3501446a-de36-11e6-86ac-f253db7791c6

Picard, M. (1995). Cultural heritage and tourist capital: Cultural tourism in Bali. In M.-F. Lanfant, J. B. Allcock, \& E. M. Brunner (Eds.), International tourism, internationalization and the challenge to identity (pp. 44-66). London, UK: Sage.

Prentice, R., \& Andersen, V. (2007). Creative tourism supply: Creating culturally empathetic destinations. In G. Richards \& J. Wilson (Eds.), Tourism, creativity and development (pp. 89-106). Abingdon, UK: Routledge.

Quantz, R. A., \& O'Connor, T. W. (1988). Writing critical ethnography: Dialogue, multivoicedness, and carnival in cultural texts. Educational Theory, 38(1), 95-109.

Rui, C. N. (2007). The working committees: From "fear" to creative activism. In K. P. Tan (Ed.), Renaissance Singapore? Economy, culture, and politics (pp. 201-216). Singapore: NUS Press.
Said, N. (2017, April 11). Arts groups tighten belt. The Straits Times. Retrieved from https://www.straitstimes. com/lifestyle/arts/arts-groups-tighten-belt

Singapore Tourism Board. (2015). Beyond tourism50: Singapore Tourism Board annual report FY2015/15. Singapore: Author.

Singapore Tourism Board. (2019). Grants overview. Retrieved May 4, 2017, from https://www.stb.gov.sg/content/ stb/en/assistance-and-licensing/grants-overview

Singapore Tourist Promotion Board, \& Ministry of Information and the Arts. (1995). Singapore: Global city for the arts. Singapore: Author.

S'pore Freeport 'not at risk' of becoming haven for illicit activities. (2014, January 15). Today. Retrieved from https://www.todayonline.com/business/spore-freeportnot-risk-becoming-haven-illicit-activities

Stallybrass, P., \& White, A. (1986). Bourgeois hysteria and the carnivalesque. In S. During (Ed.), The cultural studies reader (pp. 284-292). London, UK: Routledge.

Stolnitz, J. (1960). The aesthetic attitude. In P. Alperson (Ed.), The philosophy of the visual arts (pp. 7-14). Oxford, UK: Oxford University Press.

Tan, A. (2007). Theatre and cultures: Globalizing strategies. In K. P. Tan (Ed.), Renaissance Singapore? Economy, culture, and politics (pp. 185-200). Singapore: NUS Press.

Tan, K. P. (2007). New politics for a renaissance city. In K. P. Tan (Ed.), Renaissance Singapore? Economy, culture, and politics (pp. 17-35). Singapore: NUS Press.

Tan, W.-L. (2015). Is Singapore an arts hub yet? Retrieved April 6, 2017, from http://thepeakmagazine.com.sg/ lifestyle/is-singapore-an-arts-hub-yet/

Teo, P. (2002). Striking a balance for sustainable tourism: Implications of the discourse on globalization. Journal of Sustainable Tourism, 10(6), 459-474.

Urban Renewal Authority. (2009). Revision to the Art Incentive Sceme for New Developments in Central Area. Retrieved from https://www.ura.gov.sg/Corporate/ Guidelines/Circulars/dc09-06

Vice, S. (1997). Introducing Bakhtin. Manchester, UK: Manchester University Press.

Webb, D. (2005). Bakhtin at the seaside: Utopia, modernity and the carnivalesque. Theory, Culture \& Society, 22(3), 121-138.

Wee, C. J. W.-L. (2003). Creating high culture in the globalized "cultural desert" of Singapore. The Drama Review, 47(4), 84-97.

Williams, R. (1976). Culture. In Keywords (pp. 87-93). London, UK: Fontana Press.

Zangwill, N. (1999). Art and audience. The Journal of Aesthetics and Art Criticism, 57(3), 315-332. 